\author{
Bożena WójTOWICZ \\ Uniwersytet Pedagogiczny w Krakowie, Polska \\ Pedagogical University of Krakow, Poland
}

\title{
Ruch turystyczny a poziom rozwoju społeczno-ekonomicznego Mauritiusa
}

\section{Tourist Flows and the Level of Socio-Economic Development of Mauritius}

Streszczenie: Rozwój turystyki wywołuje pozytywne i negatywne zmiany w rozwoju społeczności lokalnej
Mauritiusa. Pozytywny aspekt to wzrastająca liczba turystów, która z jednej strony - w wielkości przyjaz-
dowego ruchu turystycznego - w znacznym stopniu determinuje wielkość wpływów z eksportu produktu
turystycznego, z drugiej zaś oddziałuje na tendencje wzrostowe wskaźników rozwoju społecznego (HDI) iza-
możności (PKB) mieszkańców. Negatywne zmiany, jakie wywołuje ruch turystyczny na gęsto zaludnionym
Mauritiusie, to tzw. przeciążenie przestrzeni turystycznej, co wiąże się nie tylko z kosztami ekologicznymi
(odpady czy konflikt o wodę pitną), ale może również powodować niechęć miejscowej ludności do bezpo-
średniego kontaktu z turystami. Celem artykułu jest ukazanie rozwoju turystyki Mauritiusa - jej pozytywne-
go i negatywnego wpływu na społeczność lokalną - na podstawie przeprowadzonych badań diagnostycznych
oraz przedstawienie, analiza i ocena roli turystyki w procesie rozwoju społeczno-ekonomicznego Mauritiusa.

\begin{abstract}
The development of tourism can cause both positive and negative changes in the development of the local society of Mauritius. The positive aspect refers to the growing number of tourists. On the one hand, it is observed in the number of incoming tourists and principally determines the amount of export revenues caused by touristic products. On the other hand, such a number indicates the increasing trends in the range of Human Development Index (HDI) and Wealth Index - understood as the size of Gross Domestic Product (GDP) of the residents. Yet, the negative changes caused by the tourist flows in the densely populated Mauritius are associated with overloading of the touristic space, which directly refers not only to the so-called ecological costs (waste or conflict related to drinking water), but it can also cause the unwillingness in the sphere of the direct contact between local people and tourists. This article aims to show the development of tourism of Mauritius and its positive and negative impacts on the local community on the basis of studies of diagnostic and performance, analysis and evaluation of the role of tourism in the socio-economic development of Mauritius.
\end{abstract}

Słowa kluczowe: czynniki rozwoju turystyki; dezurbanizacja; rozwój społeczno-ekonomiczny; ruch turystyczny; wskaźnik rozwoju społecznego; wskaźnik zamożności

Keywords: disurbanisation/desurbanisation; factors of tourism development; Human Development Index (HDI); social and economic development; tourism/tourist flows; Wealth Index (GDP)

Otrzymano: 28 grudnia 2018

Received: 28 December 2018

Zaakceptowano: 26 maja 2019

Accepted: 26 May 2019 


\section{Sugerowana cytacja / Suggested citation:}

Wójtowicz, B. (2019). Ruch turystyczny a poziom rozwoju społeczno-ekonomicznego Mauritiusa, Prace Komisji Geografii Przemysłu Polskiego Towarzystwa Geograficznego, 33(3), 100-111. doi: 10.24917/20801653.333.7

\section{WSTĘP}

Poziom rozwoju turystyki oraz atrakcyjność turystyczna Wysp Oceanu Indyjskiego jest różna - w zależności od kraju. Mimo wielu walorów, zarówno przyrodniczych, jak i antropogenicznych, w większości państw turystyka jest słabo rozwinięta (np. Madagaskar). Z drugiej strony są państwa, w których turystyka stanowi istotny, a nawet kluczowy element gospodarki (Seszele, Mauritius). Specjalizacja turystyczna Mauritiusa rozpoczęła się pod koniec lat siedemdziesiątych XX wieku, gdy turystyka zaczęła odgrywać ważną rolę w rozwoju gospodarki kraju (Warszyńska, 1995: 257) oraz infrastruktury. W przypadku małych rozwijających się państw wyspiarskich podstawowym zagrożeniem rozwoju gospodarczego jest zjawisko monokultury turystycznej ${ }^{1}$ (Giezgała, 1969, 1977; Wodejko, 1998; Jasiński, 2006, 2008; Conti, Perelli, 2007; Theuns, 2011; Kachniewska, Nawrocka, Niezgoda, Pawlicz, 2012). Mauritius to małe, wyspiarskie państwo o powierzchni $2045 \mathrm{~km}^{2}$, w którym uwarunkowania geograficzne odgrywają istotną rolę w rozwoju gospodarczym wysp (mała powierzchnia, ograniczone zasoby naturalne, izolacja od innych regionów, klęski żywiołowe) i determinują wąską specjalizację, podobnie jak w innych państwach wyspiarskich SIDS ${ }^{2}$. Cechami gospodarki Mauritiusa jest import towarów, niskie wykorzystanie miejsc pracy, kulturowa dominacja państw zachodnich, wysokie koszty transportu, infrastruktury i administracji, duża podatność na działalność przestępczą, pranie brudnych pieniędzy, korupcja, narkotyki (Kurek, 2007; Jasiński, Masłoń-Oracz, 2017). Pomimo cech pozornie wspólnych z innymi państwami SIDS nie występuje tu zjawisko tzw. monokultury turystycznej ani monokultury pomocowej, a w latach dziewięćdziesiątych nastąpił dynamiczny rozwój społeczno-gospodarczy na Mauritiusie, gdzie podstawą gospodarki stała się nie tylko turystyka, ale również rozwój usług sektora bankowego, przedsiębiorczości czy rolnictwa. Założenia badawcze przyjęte w tym artykule dotyczyły sposobu przełamania silnie ograniczających uwarunkowań środowiska przyrodniczego (brak żyznych gleb, braki słodkiej wody, ograniczona fauna i flora, brak bogactw mineralnych), które spowodowały dynamiczny rozwój wyspiarskiego afrykańskiego kraju i jego sukces społeczno-gospodarczy. Powyższe przesłanki stały się podstawą szukania odpowiedzi na pytania o przyczyny dynamicznego rozwoju Mauritiusa, w tym próba odpowiedzi na pytanie: Na ile sektor usług turystycznych przyczynił się, szczególnie w XXI wieku, do podniesienia poziomu i wzrostu szeroko rozumianego rozwoju społeczno-ekonomicznego Mauritiusa?

${ }^{1}$ Określenie „monokultura turystyczna” stosuje się do gospodarek krajów lub terytoriów silnie uzależnionych od turystyki (tempa i stabilności jej rozwoju) oraz eksportu produktu turystycznego. Do głównych cech monokultury turystycznej należą: wysoka zależność od walorów turystycznych (głównie przyrodniczych) i ich nadmierna eksploatacja, dogodne położenie względem obszarów emisji ruchu turystycznego, brak lub ograniczone możliwości rozwoju innych specjalizacji gospodarczych (Kachniewska, Nawrocka, Niezgoda, Pawlicz, 2012).

${ }^{2}$ SIDS zgodnie z klasyfikacją (UNCTAD, 2010: 5) to 29 niezależnych państw: 13 na Oceanii, 10 na Karaibach, dwa położone na Oceanie Atlantyckim i cztery na Oceanie Indyjskim - Malediwy, Mauritius, Seszele oraz Związek Komorów. 
Głównymi celami badawczymi, jakie postawiono w niniejszej pracy, były:

- analiza i ocena wielkości oraz dynamiki ruchu turystycznego w procesie rozwoju społeczno-ekonomicznego państwa na podstawie uzyskanych danych statystycznych i wyliczonych wskaźników rozwoju społeczno-ekonomicznego,

- analiza wpływów dochodów z turystyki na poziom życia i rozwój społeczno-ekonomiczny kraju na podstawie przeprowadzonych badań diagnostycznych wśród zróżnicowanej kulturowo i ekonomicznie społeczności lokalnej.

W tym artykule w analizie zostały uwzględnione lata 2002-2017 i wybrane wskaźniki rozwoju społeczno-ekonomicznego, takie jak HDI, PKB (w mld dol.), wpływy z turystyki (w mld dol.), wpływy z turystyki w PKB (w \%), PKB per capita (w dol.) oraz wpływy z turystyki per capita (w dol.) i wskaźnik rozwoju społecznego $\mathrm{HDI}^{3}$, który przy wykorzystaniu jednolitej metodologii, rekomendowanej przez UNDP, opisuje efekty w zakresie rozwoju społecznego poszczególnych krajów. Jest miarą wykorzystywaną jako kryterium przy hierarchizacji krajów według poziomu ogólnego ich rozwoju - społecznego i gospodarczego. Porównując wartości tego wskaźnika w różnych krajach, można określić dystans, jaki dzieli kraje najuboższe od najbogatszych pod względem poziomu rozwoju cywilizacyjnego. HDI jest miarą syntetyczną opartą na średniej wskaźników obejmujących trzy podstawowe sfery życia. Jest to sfera zdrowia (oceniana przez wskaźnik przeciętnej długości życia), edukacji (wskaźnik analfabetyzmu, czyli umiejętności pisania i czytania ze zrozumieniem, i wskaźnik skolaryzacji) oraz dochodu przypadającego na głowę mieszkańca (PKB per capita).

\section{ANALIZA WYBRANYCH WSKAŹNIKÓW ROZWOJU SPOŁECZNO-EKONOMICZNEGO NA MAURITIUSIE}

W latach 1990-2017 wartość HDI na Mauritiusie wzrosła z 0,619 do 0,790, czyli o 27,6 \%. W tym czasie długość życia wzrosła o 5,5 lat, a okres nauki wydłużył się o około 4 lata (średnia liczba lat nauki wzrosła o 3,6 lat). Indeks PKB na mieszkańca Mauritiusa wzrósł o około 175,5\% (1990-2017). Wskaźnik HDI w 2017 roku (0,790) był powyżej średniej 0,757 dla krajów o wysokim poziomie rozwoju społecznego i powyżej średniej 0,537 dla krajów w Afryce Subsaharyjskiej. W analizowanym okresie występują tendencje wzrostowe wskaźników HDI i PKB. Wskaźnik HDI w okresie 15 lat wzrósł z 0,687 do 0,790 w 2017 roku (piąte miejsce w 2017 roku spośród SIDS o najwyższym poziomie rozwoju społecznego na świecie, po karaibskich państwach: Bahamach, Barbadosie, Anitigui i Barbudzie oraz Seszelach na Oceanie Indyjskim). Wysoki jest progres drugiego wskaźnika (zamożności) PKB wzrósł w analizowanym okresie blisko trzykrotnie z 4,76 mld dol. w 2002 roku do 12,2 mld dol. w 2017 roku.

Wzrost wskaźników HDI i PKB jest skorelowany z wpływami z turystyki, co było szczególnie wyraźne w latach 2002-2008. Rozwój międzynarodowego ruchu turystycznego, który wykazuje tendencję wzrostową w tym okresie (z 829 mln dol. w 2002 roku do 1,823 mld dol. w 2008 roku), wpływał na PKB, które w tym okresie również wzrastało (poza niewielkim spadkiem w 2005 roku). Dane w tabeli 1 wskazują na znaczące

\footnotetext{
${ }^{3}$ Wskaźnik rozwoju społecznego - HDI (ang. Human Development Index, tłumaczone również jako wskaźnik rozwoju ludzkiego) - to syntetyczna miara opisująca zmiany w zakresie społeczno-ekonomicznego rozwoju poszczególnych krajów. Wskaźnik HDI w o wiele szerszym zakresie niż wskaźnik PKB per capita mierzy rzeczywisty poziom życia ludzi na świecie (Raport UNDP, 2015: 1).
} 
(jednak nie dominujące) oddziaływanie wpływów pochodzących z międzynarodowego ruchu turystycznego na rozwój kraju4 .

Tabela 1. Wielkość i dynamika wybranych wskaźników rozwoju społeczno-ekonomicznego Mauritiusa w latach 2002-2017

\begin{tabular}{|c|c|c|c|c|c|c|}
\hline Lata & HDI & $\begin{array}{c}\text { PKB } \\
\text { (mld dol.) }\end{array}$ & $\begin{array}{c}\text { Wpływy } \\
\text { z turystyki } \\
\text { (w mld dol.) }\end{array}$ & $\begin{array}{c}\text { Wpływy } \\
\text { z turystyki } \\
\text { w PKB (w\%) }\end{array}$ & $\begin{array}{c}\text { PKB } \\
\text { per capita } \\
\text { (w dol.) }\end{array}$ & $\begin{array}{c}\text { Wpływy } \\
\text { z turystyki } \\
\text { per capita (w dol.) }\end{array}$ \\
\hline 2002 & 0,687 & 4767 & 0,829 & 17,4 & 3957,5 & 688,2 \\
\hline 2003 & 0,696 & 5610 & 0,960 & 17,1 & 4623,3 & 791,2 \\
\hline 2004 & 0,704 & 6386 & 1,156 & 18,1 & 5229,9 & 946,8 \\
\hline 2005 & 0,713 & 6284 & 1,189 & 18,9 & 5116,0 & 968,0 \\
\hline 2006 & 0,720 & 7029 & 1,302 & 18,5 & 5696,0 & 1055,1 \\
\hline 2007 & 0,728 & 8150 & 1,663 & 20,4 & 6574,7 & 1341,5 \\
\hline 2008 & 0,734 & 9990 & 1,823 & 18,2 & 8030,1 & 1465,3 \\
\hline 2009 & 0,740 & 9129 & 1,390 & 15,2 & 7318,1 & 1114,3 \\
\hline 2010 & 0,748 & 10004 & 1,585 & 15,8 & 8000,4 & 1267,6 \\
\hline 2011 & 0,756 & 11518 & 1,808 & 15,7 & 9197,0 & 1443,6 \\
\hline 2012 & 0,765 & 11669 & 1,778 & 15,2 & 9291,2 & 1415,7 \\
\hline 2013 & 0,769 & 12130 & 1,593 & 13,1 & 9637,0 & 1265,6 \\
\hline 2014 & 0,779 & 12803 & 1,719 & 13,4 & 10153,9 & $1,363,3$ \\
\hline 2015 & 0,781 & 11682 & 1,679 & 14,4 & 9252,1 & 1329,8 \\
\hline 2016 & 0,790 & 12150 & 1,431 & 11,8 & 9613,0 & 1141,0 \\
\hline 2017 & 0,790 & 12273 & 1,529 & 12,5 & 9710,0 & $1,211,0$ \\
\hline
\end{tabular}

Źródło: Jasiński, Masłoń-Oracz (2017: 149); Human Development Report (2018); obliczenia własne za lata 2016-2017

Zmniejszenie liczby turystów na Mauritiusie w 2009 roku w stosunku do 2008 roku (tabela 2), wywołane ogólnoświatowym kryzysem (turystykę uznaje się za najczulszy barometr sytuacji kryzysowych na świecie), wpłynęło na spadek wielkości przyjazdu turystów zagranicznych do tego państwa. To z kolei miało wpływ na spadek PKB (tabela 1).

Polityka państwa wymagała podjęcia jak najszybszych działań w celu zmniejszenia skutków spadku PKB w kolejnych latach, a co za tym idzie, także tempa rozwoju społeczno-ekonomicznego wyspy. W wyniku spadku liczby przyjazdów w 2009 roku obniżono ceny usług produktu turystycznego. Spowodowało to zwiększenie ruchu turystycznego w następnym roku - do poziomu „przedkryzysowego” z 2008 roku (tabela 2) - oraz zmianę kierunku przyjazdów turystycznych przez szersze otwarcie się na inne państwa europejskie i azjatyckie (np. Hiszpanię, Włochy, Polskę, Rosję, Czechy, Chiny, Indie). Mimo obniżenia cen usług turystycznych nie osiągnięto jednak w 2010 roku zbliżonego poziomu wpływów z turystyki z 2008 roku. Nie spowodowało to spadku PKB w 2010 roku - był on nawet wyższy niż w 2008 roku. W następnych latach niewielkie wahania wpływów z turystyki również nie wpłynęły na obniżenie PKB (z wyjątkiem 2015 roku) ani wskaźnika HDI. Wskazuje to na rosnące znaczenie innych sektorów gospodarki

${ }^{4}$ Za umowną wartość, kiedy gospodarka zaczyna ulegać „degradacji” i staje się „zależna” od eksportu produktu turystycznego, w literaturze przedmiotu przyjęto w latach dziewięćdziesiątych XX wieku przekroczenie wskaźnika o 25\% (Jasiński, Anna Masłoń-Oracz, 2017). 
Mauritiusa. Niewielkie obniżenie znaczenia funkcji turystyki w procesie rozwoju społeczno-ekonomicznego potwierdza również wskaźnik wpływów z turystyki w PKB.

Dzięki działaniom podjętym przez rząd wysoki wskaźnik wpływów z turystyki (tabela 1) nie wywołał również, jak w innych regionach turystycznych na świecie, zjawiska monokultury turystycznej. Ograniczony został m.in. dalszy ilościowy rozwój bazy noclegowej oraz podjęte zostały przeciwdziałania zjawisku wypierania przez turystykę innych działów gospodarki. Zachowana została równocześnie wielkość przyjazdu turystów międzynarodowych i rozwój usług turystycznych. Nadal rozwija się rodzime rolnictwo, np. plantacja herbaty Bois Chéri (uprawia się herbatę i wytwarza się różne jej gatunki w pobliskiej fabryce), plantacje trzciny cukrowej, ananasów, wanilii. Powstały liczne farmy, np. farma krokodyli w La Vanilla Park, Park Narodowy Black River Gorges, Ogród Botaniczny w Pamplemousses czy zakład rzemieślniczy produkujący drewniane modele żaglowców w Caudan. Rozwój turystyki promowany od lat siedemdziesiątych XX wieku przyczynił się do jej postrzegania jako dziedziny gospodarki, źródła przychodów i istotnego składnika konsumpcji (Kachniewska, Nawrocka, Niezgoda, Pawlicz, 2012).

Współcześnie turystyka widziana jest jako skomplikowane i często powiązane ze sobą zarówno działania, jak i skutki ekonomiczne, polityczne, społeczno-kulturowe i środowiskowe (Jackiewicz, Klak, 2016). Tzw. przeciążenie turystyczne powoduje wzrost kosztów ekologicznych (odpady, woda pitna, dewastacja), niechęć ludności miejscowej do bezpośredniego kontaktu z turystami. Następuje powolny proces dezurbanizacji demograficznej (tabela 2) na obszarach zurbanizowanych, gdzie głównie koncentruje się ruch turystyczny, co wpływa na ograniczenie przestrzeni turystycznej przez rozbudowę infrastruktury turystycznej (przestrzeń ma związek nie tyko z turystami, ale też z jej stałymi mieszkańcami). Analiza wielkości przyjazdowego ruchu turystycznego, który w znaczny sposób generuje wielkość wpływów PKB, po 2009 roku wskazuje, że prowadzona polityka turystyczna nakierowana na utrzymanie stałych lub wyższych wpływów z turystyki może generować dodatkowe zagrożenia w sferach społeczno-kulturowych i ekologicznych. Wzrastająca liczba turystów (w 2014 roku przekroczyła $1 \mathrm{mln}$, a w 2017 roku 1,265 mln), powoduje przeciążenie przestrzeni turystycznej na gęsto zaludnionym (w porównaniu z SIDS) Mauritiusie (623 osoby na $1 \mathrm{~km}^{2}$ ). Względnie równomiernie rozłożony w ciągu roku ruch turystyczny (brak sezonowości wg danych statystycznych z lat 2011,2016, 2017) wskazuje na wyraźny wzrost odsetka liczby turystów do stałych mieszkańców (w 2015 roku - 91,2\%, a w 2017 roku około $100 \%$ ).

Tabela 2. Ludność miejscowa a liczba turystów zagranicznych na Mauritiusie w latach 2002-2017

\begin{tabular}{|l|c|c|c|c|c|c|}
\hline Lata & $\begin{array}{c}\text { Gęstość } \\
\text { zaludnienia } \\
\text { na km² }\end{array}$ & $\begin{array}{c}\text { Liczba } \\
\text { mieszkańców } \\
\text { w mln }\end{array}$ & $\begin{array}{c}\text { Liczba } \\
\text { zamieszkujących } \\
\text { obszary miejskie } \\
\text { w mln }\end{array}$ & $\begin{array}{c}\text { Ludność } \\
\text { miejska } \\
\text { względem } \\
\text { całej } \\
\text { populacji } \\
\text { w \% }\end{array}$ & $\begin{array}{c}\text { Liczba } \\
\text { turystów } \\
\text { zagranicznych } \\
\text { w mln }\end{array}$ & $\begin{array}{c}\text { Liczba turystów } \\
\text { zagranicznych } \\
\text { do stałych } \\
\text { mieszkańców \% }\end{array}$ \\
\hline 2002 & 593,4 & 1205 & 0,509 & 42,2 & 0,682 & 56,6 \\
\hline 2003 & 597,7 & 1213 & 0,510 & 42,0 & 0,702 & 57,9 \\
\hline 2004 & 601,5 & 1221 & 0,511 & 41,8 & 0,719 & 58,9 \\
\hline 2005 & 605,1 & 1228 & 0,511 & 41,6 & 0,761 & 62,0 \\
\hline 2006 & 607,9 & 1234 & 0,511 & 41,4 & 0,788 & 63,9 \\
\hline 2007 & 610,7 & 1240 & 0,511 & 41,2 & 0,907 & 73,2 \\
\hline
\end{tabular}




\begin{tabular}{|l|l|l|l|l|l|r|}
\hline 2008 & 612,9 & 1244 & 0,510 & 41,0 & 0,930 & 74,8 \\
\hline 2009 & 614,5 & 1247 & 0,509 & 40,8 & 0,871 & 69,8 \\
\hline 2010 & 616,0 & 1250 & 0,507 & 40,6 & 0,935 & 74,8 \\
\hline 2011 & 616,9 & 1252 & 0,506 & 40,4 & 0,965 & 77,1 \\
\hline 2012 & 618,7 & 1256 & 0,504 & 40,2 & 0,965 & 76,8 \\
\hline 2013 & 620,0 & 1259 & 0,503 & 40,0 & 0,993 & 78,9 \\
\hline 2014 & 621,1 & 1261 & 0,502 & 39,8 & 1,039 & 82,4 \\
\hline 2015 & 622,0 & 1262 & 0,501 & 39,7 & 1,151 & 91,2 \\
\hline 2016 & 622,4 & 1263 & 0,499 & 39,5 & 1,263 & 100,0 \\
\hline 2017 & 623,2 & 1267 & 0,500 & 39,4 & 1,265 & 99,9 \\
\hline
\end{tabular}

Źródło: Jasiński, Masłoń-Oracz (2017: 150); obliczenia własne za lata 2016-2017

Analiza rozwoju społeczno-ekonomicznego na Mauritiusie wykazała, że sektor turystyki przyczynił się do rozwoju gospodarczego kraju. Mauritius osiągnął znaczny progres w rozwoju społecznym i zamożności i plasuje się na czele gospodarek afrykańskich oraz należy do pięciu najwyżej rozwiniętych SIDS. Za podstawowe źródło sukcesu uważa się kontrolowaną i konsekwentną politykę rządu w rozwoju sektora turystycznego oraz rozwój innych sektorów, głównie rolnictwa (plantacje ananasów, herbaty, wanilii czy trzciny cukrowej), przemysłu a także usług (np. finansowo-bankowych).

\section{WPŁYW RUCHU TURYSTYCZNEGO NA ROZWÓJ SPOŁECZNO-EKONOMICZNY I JAKOŚĆ ŻYCIA W OPINII MIESZKAŃCÓW MAURITIUSA}

Ponieważ rozwój turystyki coraz mocniej wpływa na jakość życia lokalnej społeczności (Mowforth, Munt, 2003; Uysal, Perdue, Sirgy, 2012), zmienia się też jej stosunek do turystów odwiedzających jej kraj (Bandyopadhyay, Ganguly, 2015; Kowalczyk-Anioł, Zmyślony, 2017). Wynika to z przekonania, że rozwój turystyki stanowi fundament rozwoju zrównoważonego obszaru recepcji turystycznej (Mika, 2007; Sharpley, 2014; Weaver, 2017). Ogromna różnorodność kulturowa Mauritiusa jest efektem kolonialnej przeszłość wyspy, a jej mieszkańcy tworzą niezwykłą mieszankę ras, religii, wyznań, kolorów skóry i języków. Hindusi stanowią 68\%, Kreole (potomkowie afrykańskich niewolników) 27\%, Chińczycy 3\%, Francuzi około 2\%.

Badania dotyczące wpływu turystyki na gospodarkę krajów wyspiarskich w innych regionach świata prowadzili m.in.: E. Nawrocka (2010), G. Murray (2007), A. Dłużewska, A. Gonia, H. Michniewicz-Ankiersztajn, Z. Podgórski (2014), M. Mika (2014), M. Murzyn (2015). W grudniu 2016 roku podczas pobytu na Mauritiusie autorka przeprowadziła badania sondażowe wśród mieszkańców wyspy. Przebadano 194 osoby, a głównym problemem badawczym był wpływ turystyki międzynarodowej na społeczność, gospodarkę, środowisko przyrodnicze i sferę społeczno-kulturową. Badania dotyczyły pozytywnych i negatywnych zmian społeczno-ekonomicznych i środowiskowych, jakie zaszły w ich miejscowości/regionie/kraju w wyniku napływu turystów. Przeprowadzone zostały w każdym z dziewięciu dystryktów wyspy, wśród zarówno mieszkańców miasta - stolicy kraju, jak i małych miast i miejscowości. Badania były prowadzone przy dużym wsparciu dwóch Polek mieszkających od przeszło 30 lat na Mauritiusie oraz rdzennego mieszkańca Mauritiusa. W badaniach brały udział głównie osoby młode, w wieku od 25 do 44 lat, które stanowiły ponad 54\% badanych (rycina 1), na ogół dobrze wykształcone (ponad 50\% posiadało wyższe wykształcenie) (rycina 2). 
Rycina 1. Wiek respondentów

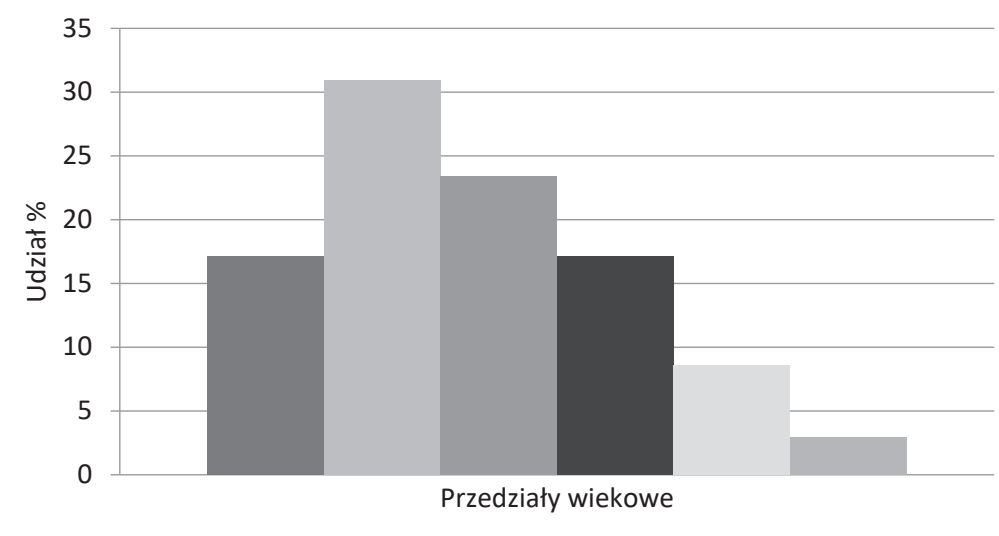

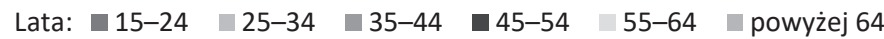

Źródło: badania własne

Rycina 2. Wykształcenie badanych

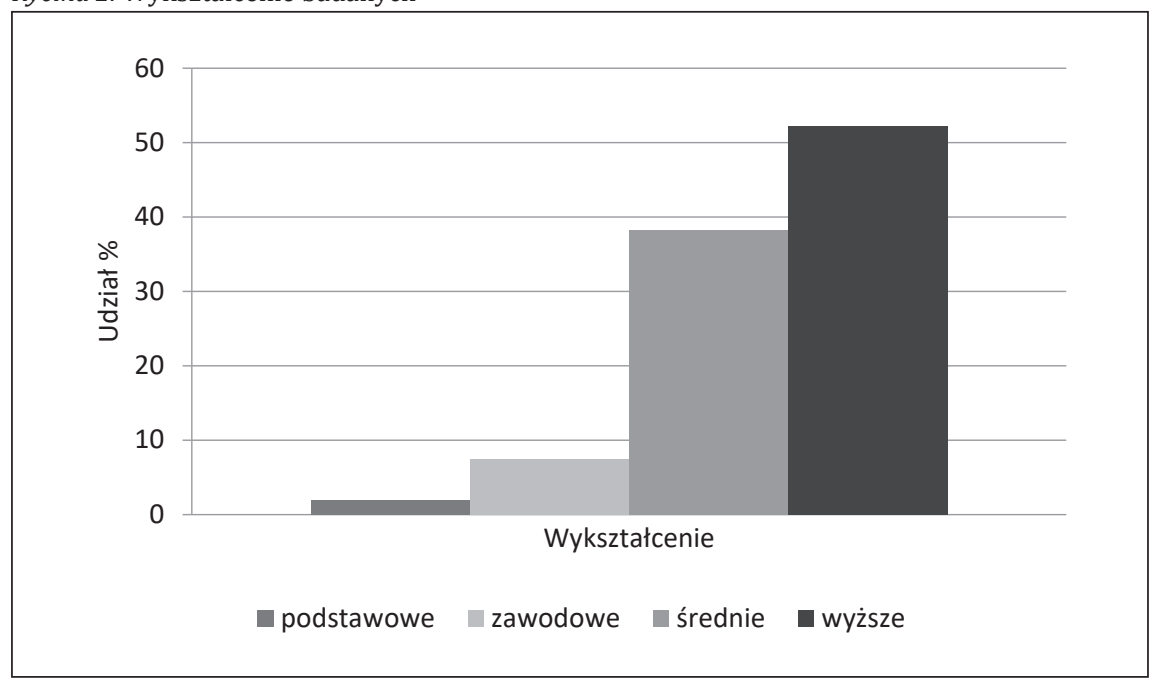

Źródło: badania własne

Jedno z pytań zawartych w kwestionariuszu ankiety dotyczyło zmian, jakie zaszły w miejscowościach badanych w wyniku napływu turystów.

Wyniki badań wykazały, że mieszkańcy pozytywnie ocenili wpływ ruchu turystycznego na miejscowości recepcyjne Mauritiusa (ponad 70\%). Mieszkańcy wskazywali na konkretne zmiany, jakie zaszły w ich miejscu zamieszkania (np. otwarto restaurację, poprawiono drogę, wyremontowano kościół, mieszkanki zaczęły wyplatać kosze itd.). Odpowiedzi negatywne respondentów stanowiły około 27\%. Kolejne pytanie mało na celu uzyskanie informacji, które czynniki (ekonomiczne, społeczne, socjologiczne, środowiskowe, kulturowe) wpływają na rozwój społeczno-ekonomiczny kraju 
Rycina 3. Ranking wypływu ruchu turystycznego na czynniki środowiskowe i społeczno-ekonomiczne Mauritiusa w opinii mieszkańców

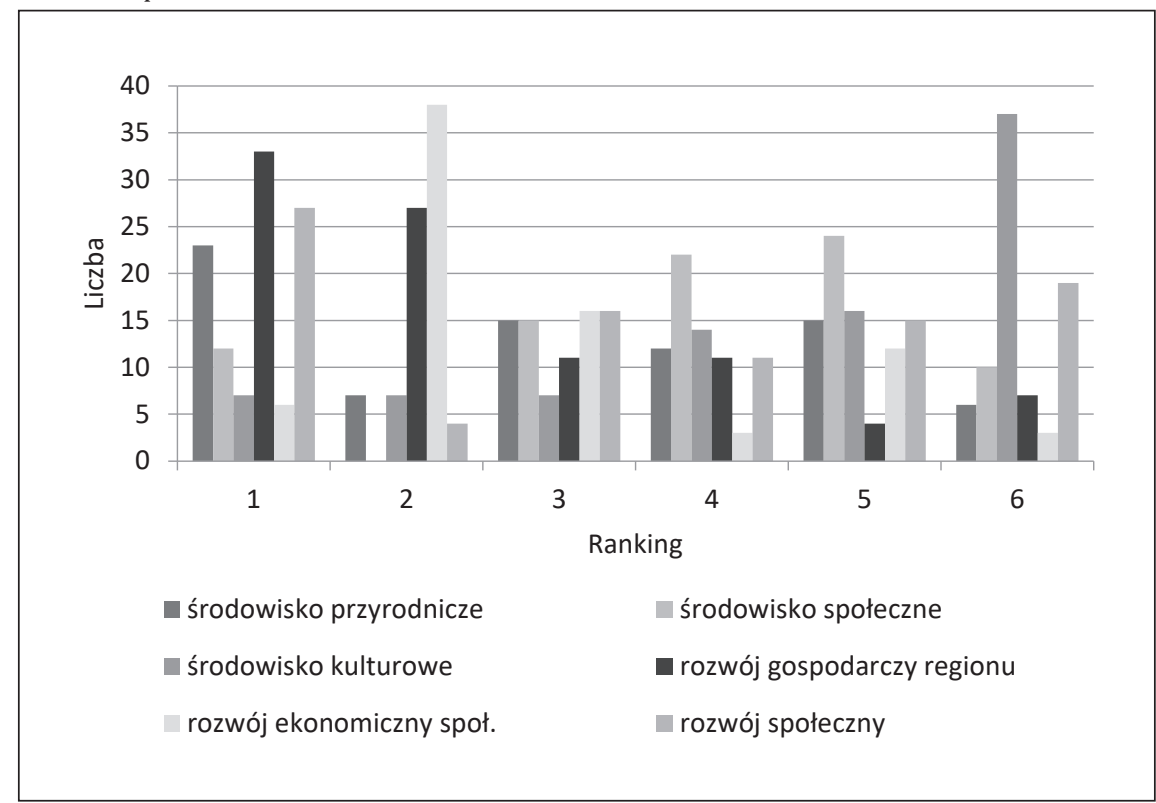

Liczba 1 oznacza największą wartość, a liczba 6 - najmniejszą.

Źródło: badania własne

i mieszkańców wyspy. Zadaniem badanych było uporządkowanie ich od najważniejszych, gdzie liczba 1 oznaczała najważniejsze, a 6 mało istotny czynnik rozwoju turystyki wywierający wpływ na mieszkańców wyspy. Ranking wpływu ruchu turystycznego na czynniki rozwoju społeczno-gospodarczego, środowiskowego i kulturowego pokazał, że badani na pierwszym miejscu wskazali wpływ na rozwój gospodarczy regionu (rozwój infrastruktury turystycznej, wzrost przychodów lokalnych, napływ kapitału zagranicznego, wzrost eksportu towarów i importu towarów na potrzeby turystyki) oraz na rozwój społeczny (powstały nowe miejsca pracy, wzrosła zamożność mieszkańców i ich dochody z turystyki, nastąpił rozwój edukacji, wzrost wykształcenia, zwłaszcza w sektorze usług). Na drugim miejscu wskazano wpływ turystyki na środowisko przyrodnicze regionu (zanieczyszczenia, odpady, hałas, problemy z wodą). Najwięcej wskazań na ostatnim miejscu w rankingu (szóste miejsce) uzyskało środowisko kulturowe (zwiększyło się zainteresowanie sztuką rodzimą, folklorem i zwyczajami), co świadczy o dużym przywiązaniu do własnych tradycji, kultury i sposobu życia mieszkańców (rycina 3).

Rozwój turystyki wywołuje pozytywne i negatywne zmiany w rozwoju społeczności lokalnej, dlatego w ankiecie zostały przedstawione różne zmiany wywołane ruchem turystycznym i rozwojem turystyki: te, które wywierają pozytywny wpływ na poszczególne grupy czynników, jak i te, które wywierają wpływ negatywny (respondenci mieli też możliwość zaproponowania innych czynników). Zdaniem badanych rozwój turystyki wywiera znacząco pozytywny wpływ na mieszkańców wyspy.

Za pozytywne aspekty rozwoju wyspy respondenci uznali czynniki ekonomiczne $(67,1 \%)$, wśród których najwyżej ocenili rozwój przedsiębiorczości i kapitału (po 
$67,1 \%)$ oraz rozwój infrastruktury turystycznej (64,9\%). Najmniej korzystnie oceniony został wzrost przychodów lokalnych (49,0\%). Jeśli chodzi o negatywny wpływ czynników ekonomicznych w ocenie mieszkańców stanowiły one co najwyżej około $20 \%$ i tu jako najważniejszy czynnik ekonomiczny negatywny wskazano wzrost poziomu cen towarów i usług oferowanych w gospodarce $(20,3 \%)$ oraz to, że środki finansowe nie zasilają miejscowej gospodarki $(19,6)$, a dochody z turystyki odpływają na zewnątrz $(18,2 \%)$.

Wśród pozytywnych czynników społecznych jako najważniejsze respondenci wskazali zwiększenie liczby miejsc pracy $(19,2 \%)$ i wzrost dochodów gospodarstw domowych $(13,9 \%)$, a wśród negatywnych - prostytucję $(9,6 \%)$ i podnoszenie cen detalicznych dla mieszkańców $(9,6 \%)$ oraz wzrost alkoholizmu $(6,4 \%)$ i pogorszenie warunków życia (hałas, odpady komunalne) (6,4\%) (tabela 3).

Czynnik socjologiczny $\mathrm{w}$ badaniach rozpatrywany był jako zmiana postaw i zachowań mieszkańców wywołana napływem turystów zagranicznych. Za pozytywne respondenci wskazali zdobycie wiedzy o europejskiej kulturze, obyczajach $(17,1 \%)$ oraz przełamanie barier językowych i większą tolerancję wobec przekonań i zachowań turystów. Za negatywne aspekty socjologiczne mieszkańcy uznali postawę konsumpcyjną $(5,4 \%)$, zanik rdzennej kultury regionalnej oraz, w niewielkim stopniu, konflikty społeczne.

Wśród kulturowych pozytywnych czynników badana społeczność najczęściej wymieniała zainteresowanie sztuką rodzimą, folklorem zwyczajami itp. $(17,1 \%)$ oraz ochronę walorów kulturowych. Jako negatywny czynnik kulturowy respondenci wskazali przemiany w środowisku społecznym miejscowości recepcyjnej $(6,4 \%)$ oraz komercjalizację kultury i sztuki (4,3\%).

Reasumując, można zauważyć, że mieszkańcy Mauritiusa dostrzegają znacznie więcej pozytywnych aspektów wpływających na ich życie na wyspie w związku z napływem turystów z różnych regionów świata, a tym samym z coraz większym rozwojem gospodarczym. Widzą także dalsze perspektywy pracy oraz poprawę bytu swoich rodzin.

Tabela 3. Pozytywne i negatywne zmiany w opinii badanych wpływające na mieszkańców wyspy, wywołane międzynarodowym ruchem turystycznym i rozwojem turystyki

\begin{tabular}{|c|c|c|c|}
\hline \multicolumn{2}{|l|}{ Pozytywne } & \multicolumn{2}{|l|}{ Negatywne } \\
\hline Ekonomiczne & Odpowiedzi w \% & Ekonomiczne & Odpowiedzi w \% \\
\hline napływ kapitału & 67,1 & $\begin{array}{l}\text { odpływ dochodów z turystyki na } \\
\text { zewnątrz }\end{array}$ & 18,2 \\
\hline $\begin{array}{l}\text { wzrost eksportu towarów } \\
\text { i importu towarów na potrzeby } \\
\text { turystyki }\end{array}$ & 61,7 & $\begin{array}{l}\text { środki finansowe nie zasilają } \\
\text { miejscowej gospodarki }\end{array}$ & 19,6 \\
\hline $\begin{array}{l}\text { rozwój infrastruktury } \\
\text { turystycznej }\end{array}$ & 64,9 & $\begin{array}{l}\text { presja inflacyjna- sezonowy } \\
\text { wzrost popytu nie jest } \\
\text { zaspokajany przez podaż }\end{array}$ & 9,6 \\
\hline $\begin{array}{l}\text { rozwój gospodarczy } \\
\text { miejscowości }\end{array}$ & 52,2 & $\begin{array}{l}\text { wzrost poziomu cen } \\
\text { towarów i usług oferowanych } \\
\text { w gospodarce }\end{array}$ & 20,3 \\
\hline wzrost przychodów lokalnych & 49,0 & \multirow[t]{2}{*}{ inne } & \multirow[t]{2}{*}{6,4} \\
\hline rozwój przedsiębiorczości & 67,1 & & \\
\hline Społeczne & Odpowiedzi w \% & Społeczne & Odpowiedzi w \% \\
\hline
\end{tabular}




\begin{tabular}{|c|c|c|c|}
\hline zwiększenie liczby miejsc pracy & 19,2 & prostytucja & 9,6 \\
\hline wzrost dochodów & 13,9 & alkoholizm & 6,4 \\
\hline edukacja - wzrost wykształcenia & 8,6 & $\begin{array}{l}\text { pogorszenie warunków życia } \\
\text { (hałas, odpady komunalne) }\end{array}$ & 6,4 \\
\hline \multirow[t]{4}{*}{ inne } & \multirow[t]{4}{*}{3,4} & szerzenie się chorób & 1,1 \\
\hline & & przestępczość & 3,2 \\
\hline & & $\begin{array}{l}\text { negatywne interakcje pomiędzy } \\
\text { mieszkańcami a turystami }\end{array}$ & 4,3 \\
\hline & & $\begin{array}{l}\text { konsekwencją rozwoju turystyki } \\
\text { jest podnoszenie cen dla } \\
\text { mieszkańców }\end{array}$ & 9,6 \\
\hline $\begin{array}{l}\text { Socjologiczne (zmiany postaw } \\
\text { i zachowań) }\end{array}$ & Odpowiedzi w \% & Socjologiczne & Odpowiedzi w \% \\
\hline przełamanie barier językowych & 16,0 & postawa konsumpcyjna & 5,4 \\
\hline $\begin{array}{l}\text { wiedza o europejskiej kulturze, } \\
\text { obyczajach }\end{array}$ & 17,1 & $\begin{array}{l}\text { zanik rdzennej kultury } \\
\text { regionalnej }\end{array}$ & 4,5 \\
\hline $\begin{array}{l}\text { tolerancja wobec przekonań } \\
\text { i zachowań turystów }\end{array}$ & 9,6 & konflikty społeczne & 2,2 , \\
\hline Kulturowe & Odpowiedzi w \% & Kulturowe & Odpowiedzi w \% \\
\hline $\begin{array}{l}\text { zainteresowanie sztuką } \\
\text { rodzimą, folklorem, zwyczajami } \\
\text { itp. }\end{array}$ & 17,1 & komercjalizacja kultury i sztuki & 4,3 \\
\hline $\begin{array}{l}\text { miejsca rdzennych } \\
\text { mieszkańców kultywujących } \\
\text { tradycje przodków }\end{array}$ & 9,6 & $\begin{array}{l}\text { zanik autentyczności kultury } \\
\text { regionalnej }\end{array}$ & 3,2 \\
\hline ochrona walorów kulturowych & 13,9 & $\begin{array}{l}\text { przemiany w środowisku } \\
\text { społecznym miejscowości } \\
\text { recepcyjnej }\end{array}$ & 6,4 \\
\hline
\end{tabular}

Źródło: badania własne

\section{Podsumowanie}

Mauritius odróżnia od innych małych państw wyspiarskich wysoki poziom rozwoju społeczno-gospodarczego. Również pod względem ekonomicznym mieszkańcom Mauritiusa powodzi się coraz lepiej. Aktualnie PKB wyspy, według parytetu siły nabywczej, wynosi około 12300 dol. i utrzymuje rosnącą tendencję. Analiza zjawiska wpływu międzynarodowego ruchu turystycznego na rozwój społeczno-ekonomiczny na Mauritiusie pozwoliła na stwierdzenie, że rozwój turystyki przyczynił się w znacznym stopniu do przyspieszenia procesu rozwoju gospodarczego oraz osiągnięcia znacznego progresu rozwoju społecznego i zamożności. Gospodarka Mauritiusa należy do najwyżej rozwiniętych gospodarek afrykańskich oraz pięciu najwyżej rozwiniętych SIDS.

Źródła sukcesu należy upatrywać w kontrolowanej i konsekwentnie prowadzonej przez rząd polityce gospodarczej. Za szczególnie istotne w tej kwestii należy uznać niedoprowadzenie do zjawiska monokultury dzięki kontrolowaniu rozwoju sektora turystycznego oraz rozwojowi innych usług (np. finansowo-bankowych). Jak wykazała analiza czynników rozwoju ekonomicznego, dywersyfikacja gospodarcza w przypadku Mauritiusa może stanowić odpowiedź na pytanie o główną przyczynę sukcesu rozwoju Mauritiusa. Podstawą gospodarki wyspy jest turystyka. Egzotyczne plaże, wodospady, bogata fauna i flora od wielu lat przyciągają tam ponad milion turystów. Wraz z rozwojem turystki pojawiały się zachodnie inwestycje - szczególnie 
w sektor bankowy, a w ostatnich latach także w elektroniczny. Badania sondażowe potwierdziły, że mieszkańcy wyspy również dostrzegli, że rozwój przedsiębiorczości, napływ i wzrost kapitału oraz rozwój infrastruktury turystycznej na wyspie, daje im większe możliwości w zakresie edukacji, wzrostu wykształcenia czy znalezienia pracy. Nastąpił również wzrost dochodów rodzin i rozwój gospodarczy ich miejscowości.

\section{Literatura \\ References}

Bandyopadhyay, R., Ganguly, T. (2015). Situating the Tourist Gaze: From Appropriation to Negotiation, Current Issuesin Tourism, 1-17.

Conti, G., Perelli, C. (2007). Governing Tourism Monoculture: Mediterranean Mass Tourism Destinations and Governance Networks. W: P.M. Burns, M. Novelli (ed.). Tourism and Politics. Global Frameworks and Local Realities. Amsterdam: Elsevier, 235-261.

Dłużewska, A., Gonia, A., Michniewicz-Ankiersztajn, H., Podgórski, Z. (2014). Współczesne problemy turystyki, Bydgoszcz: Ośrodek Sportu, Rekreacji i Edukacji w Poznaniu.

Giezgała, J. (1969, 1977). Turystyka w gospodarce narodowej. Warszawa: Polskie Wydawnictwo Ekonomiczne.

Human Development Report (2018). UNDP: United Nations Development Programme.

Jackiewicz, E.L., Klak, Th. (2016). Mass and Alternative Tourism in Latin America and the Caribbean. W: E.L. Jackiewicz, F.J. Bosco (ed.). Placing Latin America. Contemporary Themes in Geography. Lanham: Rowman \& Littelfield, 95-112.

Jasiński, M. (2006). Aspekty monokulturowe gospodarki turystycznej. Zeszyty Naukowe Kolegium Gospodarki Światowej, 20, 92-102.

Jasiński, M. (2008). Zrównoważony rozwój w monokulturowych gospodarkach turystycznych. W: S. Wodejko (red.). Zrównoważony rozwój turystyki. Warszawa: Szkoła Główna Handlowa w Warszawie.

Jasiński, M., Masłoń-Oracz, A. (2017). Rolnictwo i turystyka w rozwoju społeczno-ekonomicznym Mauritiusa. Zeszyty Naukowe Szkoły Głównej Gospodarstwa Wiejskiego, 17(3), 145-153. doi: 10.22630/PRS.2017.17.3.61

Kachniewska, M., Nawrocka, E., Niezgoda, A., Pawlicz, A. (2012). Rynek turystyczny. Ekonomiczne zagadnienia turystyki. Warszawa: Wolters Kluwer.

Kowalczyk-Anioł, J., Zmyślony, P. (2017). Turystyka miejska jako źródło protestów społecznych: przykłady Wenecji i Barcelony. Turystyka Kulturowa, 2, 7-36.

Kurek, W. (red.). (2007). Turystyka. Warszawa: Wydawnictwo Naukowe PWN.

Mika, M. (2007). Przemiany pod wpływem turystyki na obszarach recepcji turystycznej. W: W. Kurek (red.). Turystyka. Warszawa: Wydawnictwo Naukowe PWN, 406-470.

Mika, M. (2014). Założenia i determinanty podtrzymywalności lokalnego rozwoju turystyki. Kraków: Instytut Geografii i Gospodarki Przestrzennej Uniwersytetu Jagiellońskiego.

Mowforth, M., Munt, I. (2003). Tourism and Sustainability: Development and New Tourism in the Third World. London: Routledge.

Murray, G. (2007). Constructing Paradise: The Impacts of Big Tourism in the Mexican Coastal Zone. Coastal Management, 35, 339-355.

Murzyn, M. (2015). Wpływ turystyki masowej na dziedzictwo Zakopanego. Turystyka Kulturowa, $10,72-85$.

Nawrocka, E. (2010). Rozwój turystyki i rozwój zrównoważony. Prace Naukowe Uniwersytetu Ekonomicznego we Wrocławiu. Ekonomia, 140, 87-100.

Sharpley, R. (2014). Host perceptions of tourism: A review of the research. Tourism Management, 42, 37-49.

Theuns, H.L. (2011). Analiza strukturalna rozmiarów rzeczywistych i potencjalnych wycieków/ powiązań w gospodarce turystycznej Karaibów. Folia Turistica, 25(2), 123-152.

Uysal, M., Perdue, R., Sirgy, J. (red.) (2012). Handbook of Tourism and Quality-of-life Research: Enhancing the Lives of Tourists and Residents of Host Communities. Berlin: Springer Science \& Business Media. 
Warszyńska, J. (red.) (1995). Geografia turystyczna świata. Część 2. Warszawa: Wydawnictwo Naukowe PWN.

Weaver, D.B. (2017). Core-periphery Relationships and the Sustainability Paradox of Small Island Tourism. Tourism Recreation Research, 42(1), 1-11.

Wodejko, S. (1998). Ekonomiczne zagadnienia turystyki. Warszawa: Wyższa Szkoła Handlu i Prawa.

Bożena Elżbieta Wójtowicz, dr hab., prof. UP, Uniwersytet Pedagogiczny w Krakowie. Geograf, dydaktyk geografii, podróżnik, kierownik Zakładu Dydaktyki Geografii Instytutu Geografii Uniwersytetu Pedagogicznego w Krakowie. Autorka i redaktorka monografii, współautorka podręczników szkolnych. Specjalistka z zakresu geografii, turystyki i rekreacji, dydaktyki geografii oraz ochrony środowiska.

Bożena Elżbieta Wójtowicz, PhD, an assistant professor, Pedagogical University of Krakow. Geographer, geography teacher, traveller who has visited most of the European countries, Cuba, Mauritius, Mexico, India, Nepal, Egypt, Morocco, Jordan, Dominican Republic. She is the head of the Department of Didactics of Geography, Institute of Geography at the Pedagogical University of Krakow. She has published over 210 academic papers in the country and abroad. She is the author of the monograph "Geography Sustainable Development Environmental Education" and a co-author and editor of a monographic works, such as Nature of the Świętokrzyskie Voivodeship; Functions of tourism and sightseeing in the strategy of regional development in Poland; Tourism and ecology - fostering the cognitive needs and public awareness; Educational fieldwork in Świętokrzyski National Park. She is also a co-author of textbooks: Geography. Polish Landscapes 4th grade; Geography. Earth - our planet 6th grade; Natural Science 4th and 5th grade. She is a specialist in the field of geography, tourism and recreation, teaching geography, and protection of the environment.

ORCID: 0000-0002-1487-7052

\section{Adres/address:}

Uniwersytet Pedagogiczny w Krakowie

Instytut Geografii

Zakład Dydaktyki Geografii

ul. Podchorążych 2, 30-084 Kraków, Polska

e-mail: wojtowic@up.krakow.pl / boz.wojt@gmail.com 